\title{
Strobilation Of The Sea Nettle, Chrysaora Quinquecirrha, Under Field Conditions
}

Dale R. Calder

Virginia Institute of Marine Science

Follow this and additional works at: https://scholarworks.wm.edu/vimsarticles

Part of the Marine Biology Commons

\section{Recommended Citation}

Calder, Dale R., Strobilation Of The Sea Nettle, Chrysaora Quinquecirrha, Under Field Conditions (1974). Biological Bulletin, 146(3), 326-334.

$10.2307 / 1540408$

This Article is brought to you for free and open access by the Virginia Institute of Marine Science at W\&M ScholarWorks. It has been accepted for inclusion in VIMS Articles by an authorized administrator of W\&M ScholarWorks. For more information, please contact scholarworks@wm.edu. 
Reference : Biol. Bull., 146: 326-334. (June, 1974)

\title{
STROBILATION OF THE SEA NETTLE, CHRYSAORA QUINQUECIRRHA, UNDER FIELD CONDITIONS ${ }^{1}$
}

\author{
DALE R. CALDER :-
}

Virginia Institute of Marine Science, Gloncester Point, Virginia 23062

The sea nettle, Chrysaora quinquecirrha (Desor, 1848), is locally abundant during summer along the east coast of the United States from southern New England to Florida. The venomous medusa stage of this species is a significant pest and a negative economic factor, particularly in the Chesapeake Bay region.

In common with many other cnidarians, $C$. quinquecirrha undergoes an alternation between polyp and medusa stages in its life history. While the medusa population dies off annually, the sessile polyp or scyphistoma stage may remain active all year and is potentially perennial (Truitt, 1939). The scyphistoma is capable of asexual reproduction, most commonly through podocyst formation. These cysts are also resistant to adverse environmental conditions. Given favorable conditions the scyphistomae undergo strobilation, a process leading to the production of freeswimming ephyrae. The proximal portion of the polyp remaining after strobilation undergoes renewed growth, returning the scyphistoma to normal size and morphology. It is then capable of continued asexual reproduction and perhaps repeated strobilation. The ephyrae develop rapidly into medusae, which are dioecious. Fertilization results in a free-swimming planula larva, which settles on a firm substrate and develops into the scyphistoma, thereby completing the life cycle.

While the morphological details of strobilation in $C$. quinquecirrha have been described (Littleford, 1939; Cones, 1969), little is known about the ecology and seasonal dynamics of the process. The only relevant field data available to date on strobilation in this species were based on collections of ephyrae by Cargo and Schultz $(1966,1967)$. The present study was undertaken to determine (1) when strobilation begins and ends in nature; (2) the percentage of polyps strobilating at a given time; (3) the number of ephyrae produced per strobila, as observed throughout the season; (4) whether a given polyp will strobilate more than once a season under field conditions.

\section{Methods and Habitat Description}

Studies on strobilation in C. quinquecirrha were conducted from March 1972 through February 1973 in Sarah Creek on the York River, Virginia. Shells of the oyster, Crassostrea virginica, were collected using hand tongs from an old, abandoned shell accumulation in the Northeast Branch of the creek and returned to the laboratory in water-filled buckets. Examination of the shells was completed and the number of adhering scyphistomae and strobilae present determined within

1 Contribution No. 604 from the Virginia Institute of Marine Science, Gloucester Point, Virginia 23062.

2 Present Address: Marine Resources Research Institute, P.O. Box 12559, Charleston, South Carolina 29412. 
eight hours after collection. Samples were taken biweekly during March and from November through February. Weekly samples were collected during the first half of April and from August through October. From mid-April through July, sampling was conducted two to three times weekly and the results pooled for the entire week. Enough substrate was collected so that most samples contained in excess of 100 scyphistomae. Greater quantities of shell were necessary for winter and mid-summer samples because scyphistomae were less abundant during these seasons than in spring, late summer and autumn.

In the laboratory, shells were immersed in a large preparation dish containing sea water and examined under low magnification $(7-10 \times)$ using a dissecting microscope. As scyphistomae and strobilae were located and counted, they were dislodged from the shelis and placed in Stender dishes for more detailed examination

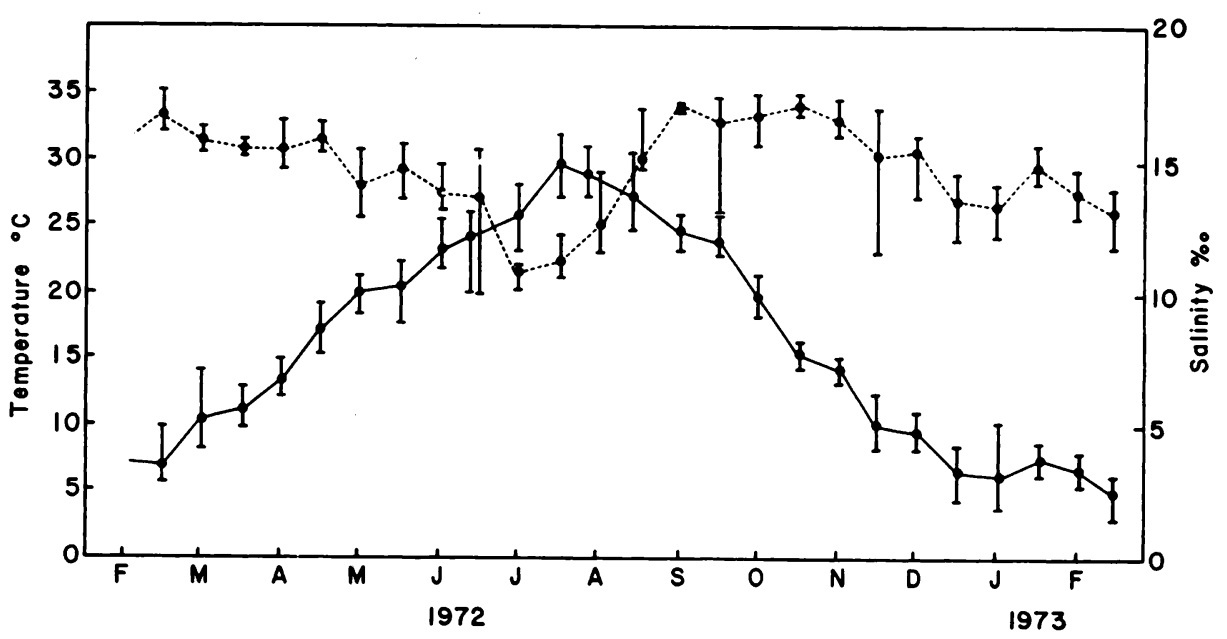

FIGURE 1. Salinity (dashed line) and water temperature (solid line) in Sarah Creek.

Intersects indicate mean, vertical lines the range for the previous two-week interval.

at higher magnification. Small polyps, as well as large ones, were counted during the study. Three methods were used in identification of scyphistomae: (1) examination of the nematocyst complement (Calder, 1971); (2) determination of mouth shape (Morales-Alamo and Haven, 1974); (3) identification of the ephyrae liberated following strobilation (Calder, 1972).

All field-collected strobilae that had not liberated ephyrae prior to collection were placed individually in vials containing $4.5 \mathrm{ml}$ of filtered sea water (17\% salinity). These strobilae were held at $25^{\circ} \mathrm{C}$ (approximating ambient summer water temperatures) in an incubator until the total number of ephyrae produced could be determined. Identification was based on the morphology of the released ephyrae. After liberation of ephyrae, scyphistomae were removed to petri dishes and held in the laboratory until several had reattached. Upon reattachment, the exact location of each polyp was recorded and the petri dishes were secured to a retrievable rack and submerged, bottom up, in Sarah Creek. Scyphistomae were 
checked for restrobilation in the field several times weekly with a $10 \times$ hand lens. New polyps produced by asexual reproduction during the study were removed from the dishes.

Hydrographic data, including salinity, dissolved oxygen, water temperature, and water transparency, were collected several times weekly in Sarah Creek throughout the study.

TABLE 1

Numbers of scyphistomae and strobilae in samples from Sarah Creek

\begin{tabular}{|c|c|c|c|c|}
\hline Time interval & $\begin{array}{c}\text { No. } \\
\text { samples }\end{array}$ & $\begin{array}{l}\text { No. } \\
\text { scyphistomae }\end{array}$ & $\begin{array}{l}\text { No. } \\
\text { strobilae }\end{array}$ & $\begin{array}{l}\text { Per cent of } \\
\text { polyps } \\
\text { strobilating }\end{array}$ \\
\hline $\begin{array}{l}\text { 5 March-1 April } \\
\text { 2-15 April } \\
\text { 16-22 April } \\
\text { 23-29 April } \\
\text { 30 April-6 May } \\
\text { 7-13 May } \\
14-20 \text { May } \\
21-27 \text { May } \\
\text { 28 May-3 June } \\
\text { 4-10 June } \\
\text { 11-17 June } \\
18-24 \text { June } \\
\text { 25 June-1 July } \\
\text { 2-8 July } \\
9-15 \text { July } \\
\text { 16-22 July } \\
\text { 23 July-5 August } \\
\text { 6-12 August } \\
13-19 \text { August } \\
\text { 20-26 August } \\
\text { 27 August-2 September } \\
\text { 3-9 September } \\
\text { 10-16 September } \\
\text { 17-23 September } \\
\text { 24-30 September } \\
1-7 \text { October } \\
\text { 8-14 October } \\
\text { 15-21 October } \\
\text { 22-28 October } \\
\text { 29 October-4 November } \\
5 \text { November } 1972-3 \text { March } 1973\end{array}$ & $\begin{array}{l}2 \\
2 \\
2 \\
3 \\
3 \\
3 \\
3 \\
3 \\
3 \\
3 \\
2 \\
2 \\
2 \\
2 \\
2 \\
1 \\
1 \\
2 \\
1 \\
1 \\
1 \\
1 \\
1 \\
1 \\
1 \\
1 \\
1 \\
1 \\
1 \\
8\end{array}$ & $\begin{array}{r}110 \\
173 \\
249 \\
401 \\
406 \\
416 \\
520 \\
311 \\
336 \\
409 \\
244 \\
205 \\
273 \\
255 \\
138 \\
93 \\
82 \\
169 \\
128 \\
159 \\
251 \\
202 \\
225 \\
229 \\
198 \\
237 \\
247 \\
215 \\
251 \\
876\end{array}$ & $\begin{array}{r}0 \\
0 \\
5 \\
48 \\
41 \\
54 \\
60 \\
78 \\
42 \\
114 \\
41 \\
37 \\
38 \\
28 \\
7 \\
9 \\
- \\
3 \\
1 \\
3 \\
4 \\
0 \\
1 \\
1 \\
0 \\
1 \\
0 \\
0 \\
0 \\
0 \\
0\end{array}$ & $\begin{array}{r}0.0 \\
0.0 \\
2.0 \\
10.7 \\
9.2 \\
11.5 \\
10.3 \\
20.1 \\
11.1 \\
21.8 \\
14.4 \\
15.3 \\
12.2 \\
9.9 \\
4.8 \\
8.8 \\
3.5 \\
0.6 \\
2.3 \\
2.5 \\
0.0 \\
0.5 \\
0.4 \\
0.0 \\
0.5 \\
0.0 \\
0.0 \\
0.0 \\
0.0 \\
0.0\end{array}$ \\
\hline
\end{tabular}

Sarah Creek is located on the north shore of the lower York River, $9 \mathrm{~km}$ from Chesapeake Bay. The creek divides into two branches, the Northwest and the Northeast, each having depths of $2 \mathrm{~m}$ for about $1.3 \mathrm{~km}$ (U. S. Coast Pilot, 1971). The shoreline is sandy at the entrance but elsewhere is predominantly muddy and bordered with saltwater cordgrass (Spartina alterniflora). The bottom consists of mud, except for accumulations of shell on private oyster grounds and near oyster houses. These shells provide substrate for a variety of epifaunal organisms, including scyphistomae of Chrysaora quinquecirrha. 
Mean tidal range in the creek is about $0.9 \mathrm{~m}$. Currents are weak except at the narrow entrance, where velocities reach about $0.5 \mathrm{~m} / \mathrm{sec}$. Hydrographic conditions fluctuate markedly in the creek (Fig. 1), both seasonally and in response to local weather conditions. Freshwater runoff from heavy rains rapidly decreases salinity and increases water turbidity. Salinities were below normal throughout the Chesapeake Bay system in 1972 due to heavy rains during the autumn of 1971 . Unusually wet weather continued through the spring of 1972 and was followed by heavy rainfall during Tropical Storm AGNEs in late June 1972 that further depressed salinities. In Sarah Creek salinities reached a minimum of $9.94 \%$ on 29 June. Waters of the creek are normally turbid, with maximum Secchi disc visibilities of about $2 \mathrm{~m}$ being attained in late autumn and early winter. In summer, visibilities are consistently below $1 \mathrm{~m}$, and may drop as low as $0.3 \mathrm{~m}$ following heavy rainfall. Water temperatures increase or decrease rapidly depending upon air temperature.

TABLE II

Numbers of ephyrae liberated per strobila in samples from Sarah Creek. Strobilae having liberated ephyrae before collection were not included

\begin{tabular}{l|c|c|c}
\hline Month & No. strobilae & No. ephyrae & Ephyrae/strobila \\
\cline { 2 - 4 } April & 35 & 292 & 8.3 \\
May & 127 & 752 & 5.9 \\
June & 160 & 704 & 4.4 \\
July & 28 & 106 & 3.8 \\
August & 6 & 26 & 4.3 \\
September & 1 & 7 & 7.0 \\
October & 1 & 4 & 4.0 \\
Totals & 358 & 1891 & 5.3 \\
\hline
\end{tabular}

Although the creek occasionally freezes over in cold winter periods, it did not do so in 1972-1973. Summer water temperatures reached a maximum of $32^{\circ} \mathrm{C}$. There was no evidence of oxygen depletion in creek waters during the study. Dissolved oxygen values averaged $10.1,7.8,7.1$, and $8.4 \mathrm{mg} /$ liter for winter, spring, summer and autumn, respectively. The lowest value recorded was $4.4 \mathrm{mg} / \mathrm{liter}$ following a heavy rain on 4 May 1972. The creek is sheltered from wind, and maximum wave height observed in the creek during the study was about $0.3 \mathrm{~m}$.

\section{RESULTS}

Scyphistomae of $C$. quinquecirrha were collected in Sarah Creek throughout the year, although most survived as podocysts during the coldest part of the winter. Strobilation extended over a period of 24 weeks during the study. Strobilae were first observed on 18 April, when three of 115 polyps collected were beginning to show segmentation. Water temperature on this date was $16.8^{\circ} \mathrm{C}$, having risen from $14.9^{\circ} \mathrm{C}$ four days earlier. After 20 April, when two additional strobilae were collected, numbers of strobilating polyps in the samples rapidly increased (Table I). Strobilation peaked during May and June, with a maximum weekly percentage recorded during 4-10 June. Peak value for a single sample was obtained on 5 June 
when $25.4 \%$ of the polyps collected were undergoing strobilation. Fresh water from Tropical Storm AgNes depressed salinities in Sarah Creek during late June (Fig. 1), but strobilation was already in decline and was not noticeably affected. Although strobilation continued throughout the summer, the percentage of polyps strobilating at a given time after June was relatively small. Only three strobilae were collected after August, the last on 2 October. These three were normal morphologically, and typical ephyrae were produced.

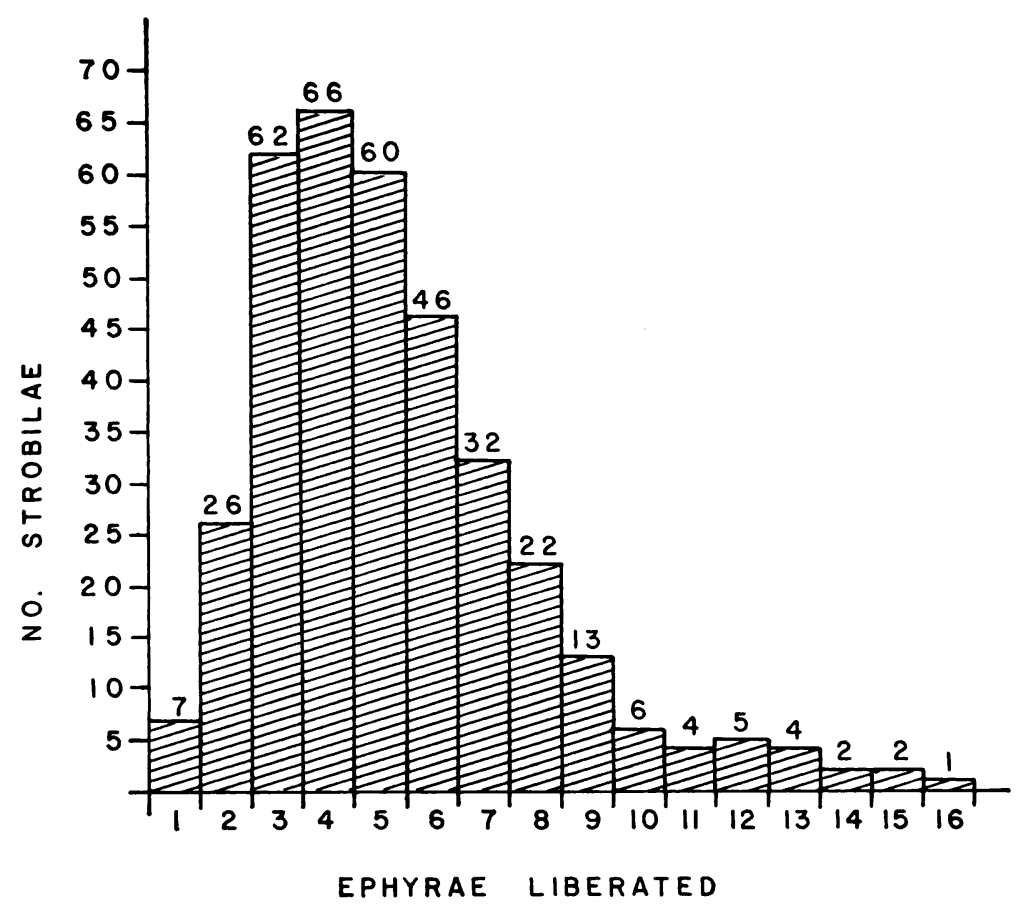

FigURE 2. Frequency distribution of numbers of ephyrae produced per strobila.

Pulses of strobilation were evident from the samples. Peaks of strobilation for 23-29 April, 7-13 May, 21-27 May, 4-10 June, and 18-24 June were followed by lower levels on 30 April-6 May, 14-20 May, 28 May-3 June, 11-17 June, and 25 June-1 July respectively. These fluctuations did not correlate with any observed environmental factor except tidal rhythm. Strobilation peaks coincided with periods of increasing tidal amplitude as indicated in the 1972 tide tables (National Ocean Survey, 1971).

The number of ephyrae produced per strobila varied from one to 16 during the study (Fig. 2). The mean number of ephyrae per strobila was higher in spring than during the summer (Table II).

Studies conducted in late spring and early summer demonstrated that a scyphistoma can strobilate more than once in nature during a given season. Of 48 scyphistomae reimmersed in Sarah Creek following strobilation, 22 strobilated again 
once, 11 strobilated twice, four strobilated three times and two strobilated four times. Most of the scyphistomae were observed for a relatively brief interval before being lost ; the mean length of time a polyp remained on the dishes was 24 days. The two polyps that restrobilated four times were monitored over an interval of six weeks. Losses of scyphistomae were attributed largely to nudibranch predation, although some evidently became detached during strobilation.

\section{Discussion}

Waters of the Chesapeake Bay system are characterized by a wide annual range in temperature. Under these conditions strobilation in C. quinquecirrha undergoes a definite seasonal periodicity. During this study strobilation began abruptly in April as the water temperature approached $17^{\circ} \mathrm{C}$. After reaching a peak during May and June, the process did not terminate as suddenly as it had begun but continued at a diminished rate throughout the rest of the summer and early autumn. No strobilation occurred from November through March, when cold water temperatures prevailed. The influence of water temperature on strobilation in $C$. quinquecirrha has been determined experimentally in laboratory studies by Cones (1969) and Loeb (1972). In these experiments strobilation was induced by elevating the water temperature in cultures of polyps maintained under cold conditions. Manipulation of water temperature has also been used to trigger strobilation in other species of scyphozoans under laboratory conditions (Russell, 1970).

Water temperature is not always as significant in the control of strobilation as it is for C. quinquecirrha in Chesapeake Bay. Thiel (1962) concluded that water temperature was not very important in regulating strobilation of Aurelia aurita in the Kieler Förde. He found that strobilation could occur throughout the year, and that there were two peaks, both coinciding with plankton blooms. His conclusion that food supply was the major factor controlling strobilation in the Kieler Förde was further confirmed through supplemental feeding experiments.

In addition to temperature and nutrition, a number of other factors are known to affect strobilation, including salinity, dissolved oxygen, light, chemicals, symbiotic zooxanthellae, and $\mathrm{pH}$ (Spangenberg, 1968: Russell, 1970). As with temperature. the relative significance of these factors varies from species to species and from location to location. Even within a given species, populations from different geographic areas may respond differently to the same factor. In $A$. aurita, strobilation occurs at much lower temperatures in European populations than in populations from Texas (Spangenberg, 1965; Russell, 1970). As Russell suggested, such differences are probably due to the existence of a number of races in this widespread species.

A series of pulses in the rate of strobilation was evident during this survey. An analogous series of peaks in the abundance of ephyrae in St. John Creek, Maryland, was noted by Cargo and Schultz (1967). They hypothesized that (1) the early peak was due to strobilation of polyps having survived through the winter, (2) a second and larger peak was due to the excystment of polyps from podocysts and their subsequent strobilation, and (3) later peaks were due to repeated strobilation in polyps. While not disagreeing with this hypothesis, the pulses of strobilation observed in Sarah Creek occurred in such a regular succession that another explanation is possible. In being about two weeks apart, the peaks coincided with periods 
of increasing tidal amplitude, suggesting a semilunar periodicity in strobilation rate. It is also possible that chemical stimuli contribute to the pulses of strobilation. Loeb (1974) indicated that a neck-inducing factor (NIF) apparently plays a significant role in triggering strobilation in $C$. quinquecirrha.

Information regarding the number of ephyrae produced during strobilation in C. quinquecirrha varies considerably. According to Littleford and Truitt (1937), Littleford (1939), Truitt (1939) and Cones (1969), the number is relatively constant, varying only from five to six. Cargo and Schultz (1966) observed a range from three to nine, with a mode of five. Under laboratory conditions numbers from one to 16 (Crawford and Webb, 1972) and from five to 20 (Loeb, 1972) have been reported. The number produced by strobilae collected in nature during this study varied from one to 16 , with a mean of five and a mode of four. Numbers of ephyrae per strobila were evidently highest early in the season. Monodisc strobilae were rare and typically smaller than those undergoing polydisc strobilation.

The phenomenon of strobilation in scyphozoans consists of two separate processes, namely segmentation and metamorphosis (Thiel, 1938; Spangenberg, 1968). This results in the derivation of several new organisms from the single original entity. In the segmentation process there remains after strobilation a small portion of the scyphistoma that is capable of totally regenerating itself and repeating. the process. The occurrence of repeated strobilation in a given scyphistoma has been reported in several species. Gohar and Eisawy (1961) observed strobilation twice in succession within three weeks in polyps of Cassiopea andromeda. In Mastigias papua strobilation occurred three times in seven weeks (Sugiura, 1963), and Cephea cephea strobilated three times within a three week interval (Sugiura, 1966). Thiel (1962) demonstrated that a scyphistoma of $A$. aurita in the Kieler Förde could strobilate up to four times a year. In $C$. quinquecirrha, Littleford (1939) and Truitt (1939) noted that individual polyps underwent strobilation each summer for four successive years. Subsequent laboratory experiments by Cargo and Schultz (1967) and Loeb (1972) indicated that scyphistomae of C. quinquecirrha could strobilate repeatedly. Studies conducted in Sarah Creek during 1972 confirmed that repeated strobilation can also occur in nature.

I am indebted to Michael A. Cavell, Jr., for assisting in the field work, and to Dr. M. L. Wass for comments on the manuscript. This study was conducted in cooperation with the U. S. Department of Commerce, National Oceanic and Atmospheric Administration, National Marine Fisheries Service, under Public Law 89-720, Jellyfish Act, Contract No. N-043-226-72(G) to Dr. P. L. Zubkoff, Project Coordinator.

\section{SUMMARY}

1. A 12-month study of strobilation in the sea nettle, Chrysaora quinquecirrha, was conducted under natural conditions in the field. Observations were made in a creek of the Chesapeake Bay system where scyphistomae of $C$. quinquecirrha were known to occur and where medusae are normally abundant each year. 
2. Strobilation was seasonal in occurrence, beginning in April and lasting until early October.

3. Maximum rates of strobilation occurred during May and June. Instead of a single sustained peak during this period, strobilation was protracted into a series of pulses that coincided with periods of increasing tidal amplitude, suggesting a semilunar periodicity. Although strobilation continued into October. the percentage of polyps strobilating after June was relatively low.

4. The number of ephyrae produced per strobila varied from one to 16 , with a mean of five and a mode of four. The mean number of ephyrae per strobila was higher in spring than during summer.

5. Observations on individual scyphistomae attached to petri dishes confirmed that repeated strobilation can occur in polyps of $C$. quinquecirrha in nature.

\section{LITERATURE CITED}

Calder, D. R., 1971. Nematocysts of polyps of Aurelia, Chrysaora, and Cyanea, and their utility in identification. Trans. Amer. Microscop. Soc., 90: 269-274.

Calder, D. R., 1972. Development of the sea nettle Chrysaora quinquecirrha (Scyphozoa, Semaeostomeae). Chesapeake Sci., $13: 40-44$.

Cargo, D. G., AND L. P. Schultz, 1966. Notes on the biology of the sea nettle, Chrysaora quinquecirrha, in Chesapeake Bay. Chesapeake Sci., 7: 95-100.

Cargo, D. G., ANd L. P. Schultz, 1967. Further observations on the biology of the sea nettle and jellyfishes in Chesapeake Bay. Chesapeake Sci., 8: 209-220.

Cones, H. N., Jr., 1969. Strobilation of Chry'saora quinquecirrha polyps in the laboratory. Virginia J. Sci., 20 : 16-18.

Crawford, M. A., ANd K. L. WebB, 1972. An ultrastructural study of strobilation in Chrysaora quinquecirrha with special reference to neurosecretion. J. Exp. Zool., 182: 251-269.

Gohar, H. A. F., ANd A. M. Eisawy, 1961. The development of Cassiopea andromeda (Scyphomedusae). Publ. Mar. Biol. Sta. Al-Ghardaga, 11: 147-190.

LrTtLefoRd, R. A., 1939. The life cycle of Dactylometra quinquecirrha L. Agassiz in the Chesapeake Bay. Biol. Bull., 77 : 368-381.

Littleford, R. A., And R. V. Truitt, 1937. Variation of Dactylometra quinquecirrha. Science, 86: $426-427$.

LoEB, M. J., 1972. Strobilation in the Chesapeake Bay sea nettle Chrysaora quinquecirrha. I. The effects of environmental temperature changes on strobilation and growth. $J$. Exp. Zool., 180 : 279-291.

LOEB, M. J., 1974. Strobilation in the Chesapeake Bay sea nettle, Chrysaora quinquecirrha. II. Partial characterization of the neck-inducing factor from strobilating polyps. Comp. Biochem. Physiol., 47A : 291-301.

Morales-Alamo, R., and D. S. Haven, 1974. Atypical mouth shape of polyps of the jellyfish, Aurelia aurita, from Chesapeake Bay, Delaware Bay, and Gulf of Mexico. Chesapeakc Sci., 15 : 22-29.

National Ocean Survey, 1971. Tide Tables 1972. East coast of North and South America including Greenland. U. S. Government Printing Office, Washington, D. C., 290 pp.

Russel., F. S., 1970. The Medusac of the British Isles. II. Pelagic Scyphozoa, zith a supplement to the first volume on Hydromedusae. Cambridge University Press, Cambridge, 284 pp.

Spangen berG, D. B., 1965. A study of strobilation in Aurelia aurita under controlled conditions. J. Exp. Zool., $160: 1-9$.

SpangenberG, D. B., 1968. Recent studies of strobilation in jellyfish. Oceanogr. Mar. Biol. Ann. Rer'. $6:$ : 231-247.

Sugrura, Y., 1963. On the life-history of rhizostome medusae. I. Mastigias papua L. Agassiz. Annot. Zool. Jap., 36 : 194-202. 
Sugrura, Y., 1966. On the life-history of rhizostome medusae. IV. Cephea cephea. Embryulogia, 9 : 105-121.

ThIEL, H., 1962. Untersuchungen über die Strobilisation von Aurelia aurita Lam. an einer Population der Kieler Förde. Kieler Meeresforsch., 18: 198-230.

Thiel, M. E., 1938. Uber eine Scyphistomabildung durch Strobilisation und ihre phylogenetische und eidonomische Bedeutung. Zool. Anz., 121 : 97-107.

Truitr, R. V., 1939. Stoloniferous, pedal disk and somatic budding in the common sea nettle, Dactylometra quinquecirrha, L. Agassiz. Bull. Natur. Hist. Soc. Maryland, 9: 38-39.

U. S. Const Pilot 3, 1971. Atlantic coast. Sandy Hook to Cape Henry. National Ocean Survey, Washington, D. C., 246 pp. 